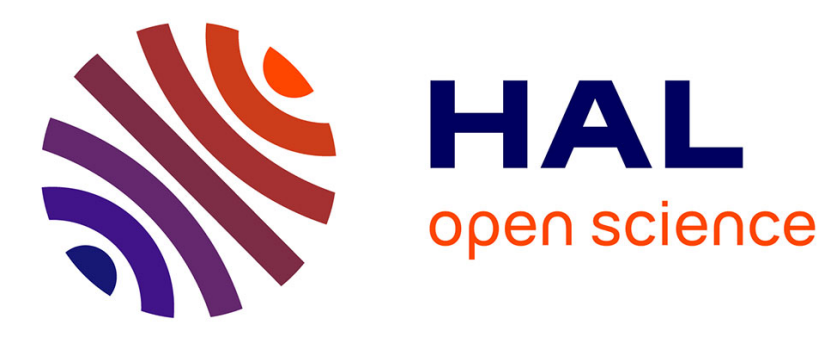

\title{
The Soundscape of a City in the Nineteenth Century Olivier Balaÿ
}

\section{To cite this version:}

Olivier Balaÿ. The Soundscape of a City in the Nineteenth Century. Ian Biddle; Kirsten Gibson. Cultural Histories of Noise: Sound and Listening in Europe, 1300-1918, Routledge, pp. 221-235, 2016, 978-1-409-44439-8. hal-02164588

\section{HAL Id: hal-02164588 \\ https://hal.science/hal-02164588}

Submitted on 11 Jul 2019

HAL is a multi-disciplinary open access archive for the deposit and dissemination of scientific research documents, whether they are published or not. The documents may come from teaching and research institutions in France or abroad, or from public or private research centers.
L'archive ouverte pluridisciplinaire HAL, est destinée au dépôt et à la diffusion de documents scientifiques de niveau recherche, publiés ou non, émanant des établissements d'enseignement et de recherche français ou étrangers, des laboratoires publics ou privés. 


\title{
the Soundscape of a City in the Nineteenth Century
}

\author{
Olivier Balä̈
}

\section{Introduction}

This chapter retraces part of the history of the transformation of the 'soundscape of 19th century towns' ${ }^{1}$ It shows, on the basis of the study of the urban fabric of Lyon, France, that developments made in the middle of the century changed the conditions under which sounds were produced and propagated: urban 'repairs', the widening of thoroughfares and the removal of overhangs, corbelled constructions and awnings, led slowly but surely to changes in what was heard, to average intensities, lower frequencies and continuous noises that gradually put an end to high-intensity noises or silence and high-pitched, intermittent, human sounds. $^{2}$

\section{the Acoustic Metamorphoses of the Street}

The urbanscape is not only organized in terms of the visual, but also by sound. Sounds propagate in different ways depending on the width of streets and the nature of the materials and decorative elements used for façades. Developing a space necessarily changes its original acoustic make-up. By modifying the width of streets and the height of buildings, and introducing regulations governing the architectural design of façades, the authorities affected the characteristics of the urban soundscape.

The end of the first half of the nineteenth century was a crucial moment in urban transformation. In Lyon, much as in other large towns, the local and national government authorities, who were responsible for defining urban ills and the appropriate remedial policies, made alterations on an unprecedented scale that changed the urban morphology inherited from previous centuries and paved the way for the shaping of the acoustic environment that we find in the contemporary public space.

The streets of eighteenth-century Lyon, as we know, were narrow and lined with high buildings. The façades were decorated with various cavities and projections. Visiting travellers were struck by the considerable height of the buildings lining the narrow streets of the town centre. In Lyon, as one visitor put it, 'you only see a sample of the sky'. 3 


\section{Olivier Balä̈}

The historian Maurice Garden refers to an expert appraisal dating from 1723-24 and covering the whole of Rue des Prêtres, one of the busiest thoroughfares close to Saint-Georges' gate and the wooden Archevêché bridge. The street was 9 foot wide ( 3 metres) and there was not enough room for two carts to pass. Two-thirds of the length of Rue du Boeuf (in the Saint-Jean district) was trapped between three buildings, with the same width of 9 feet. Rue du Plat-d'Argent (on the central peninsula) was no more than 14 foot wide (4.2 metres). Rue Royale, which was built in the eighteenth century in what is now the Croix-Paquet district (at the bottom of the Croix-Rousse slopes) was 24 foot wide (7.20 metres). That is 'much more than the old streets', writes Garden. ${ }^{4}$

At the same time, at least three-quarters of the buildings in the Hôtel-Dieu district had at least five storeys. Around the corn market (Cordeliers district), some 41 per cent of buildings had five storeys or more. Around the town hall (on what is now Place des Terreaux) 28 per cent of the buildings boasted six floors. Taking the city as a whole, without its suburbs, 71 per cent of buildings had more than four storeys. ${ }^{5}$

From 1823, with successive additions to street by-laws, the Lyon authorities banned various devices that absorbed and dispersed sound, and, inadvertently, established street acoustics that were less satisfactory in terms of sound clarity. Several by-laws banned dyers, drapers, cleaners and the like from setting up poles and hanging out fabric. Such drapes were only permitted if they were located at least 6 metres above the ground and did not jut out more than 80 centimetres into the street. Encorbelled additions were banned, and existing elements were gradually demolished as structures were rebuilt or repaired. Under article III of a police by-law issued on 9 December 1823, awnings were only allowed on squares and quays, never in the streets. However, permission would be granted subject to agreement by the occupants of upper floors. There was no question of awnings being supported by wooden columns driven into the paving stones. This was still allowed in 1813 and proved a considerable hindrance to traffic to judge by an advisor to the Préfet, who wrote: 'On Rue du Plat-d'Argent a dyer who has hung out fabric is taking up more than half the width of the street'. ${ }^{6}$ Under the awnings, fixed displays jutting out by more than 20 centimetres (also known as montres) were still authorized in 1813 . But by 1825 the rules had been changed. Cafes were only allowed to set up chairs and benches on squares and quays, on condition that they did not encroach on public thoroughfares by more than 1.5 metres. Elsewhere placing chairs outside cafes was forbidden.

The drawings in Figure 11.1 show how, in the same street, sound propagation changes as a consequence of the drapes and the size of outcrops, encorbelled elements and signs located on the façades. For example the fabric of awnings absorbs low and high frequencies. Cornices diffuse vocal frequencies well. Glass canopies, authorized in streets more than 10 metres wide and above shops, protect dwellings on upper floors.

The cross-section views showing street dimensions regroup this data with the rules for the height of various elements found in a by-law dated 15 November 1849. The drawings show how the profile of the street changes the sound level, 

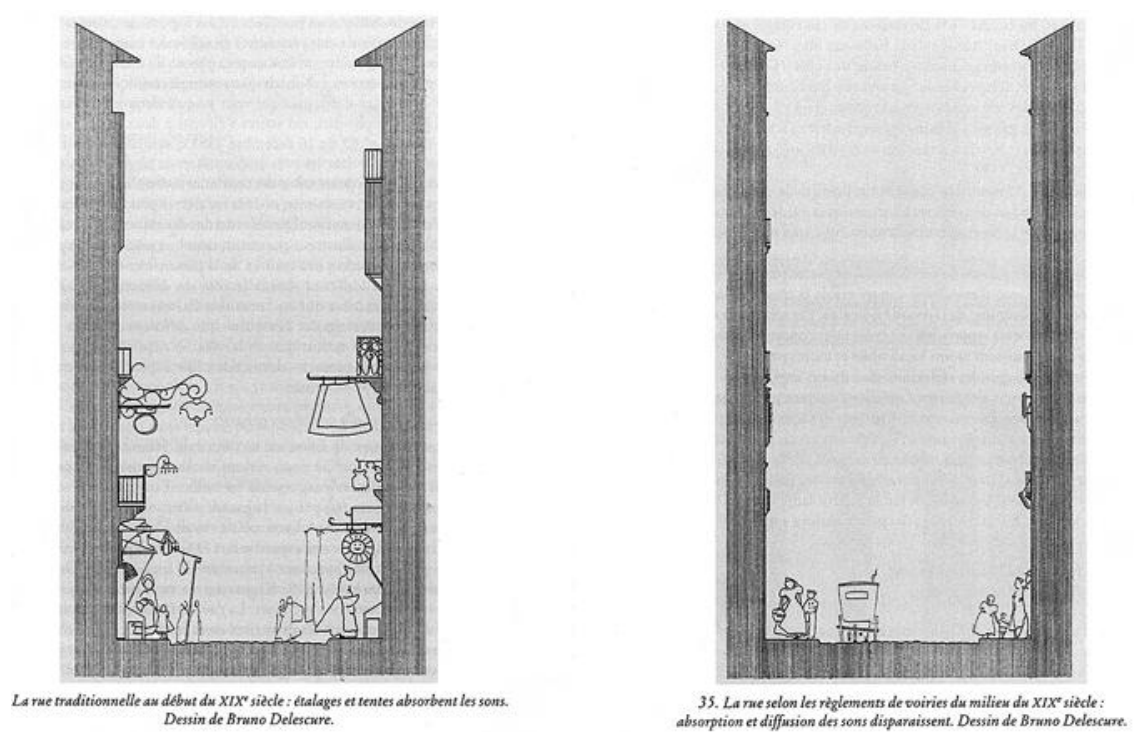

Figure 11.1 At the beginning of the nineteenth century, hangings and tents absorbed sound. In the middle of the nineteenth century absorption and diffusion of sounds disappeared. Drawing by Bruno Delescure.

due to acoustic reflection on the walls, regardless of the nature of the noise and the number of sources (one or more voices, for example). Acoustic analysis, which we will develop in greater detail below, can be used to specify the reverberation parameters for each case. For a given sound level for city activity, the reverberation of a narrow street heightens the perception of human density. Reflected sound is multiplied by the closeness of the walls, creating conditions in which sources are more difficult to locate and isolate for the listener.

In the wider streets less sound is refl Sounds do not reverberate for so long because the streets open more onto the sky, into which sound may escape. The opening onto the sky increases from 12 per cent in a narrow street (fi metres wide) to 20 per cent in a street twice as wide. The difference in the length of time streets reverberate should not be neglected (about 0.5 to 1 second). Depending on whether the street is narrow or wide, the human voice will linger differently (the sound envelope of the voice is amplifi or there is an echo.

\section{Urban transformation Changes the Sound Atmosphere}

But there is more to the sound history of the town than just the existence of sound sources and auditory presences. Something intermediate intervenes, reshaping the sound source, boosting or weakening its range, filtering its spectrum and shaping its duration. It is, then, the morphology and material of the place that has the biggest impact on how the different ways of sounding linger on. 


\section{Olivier Balä̈}
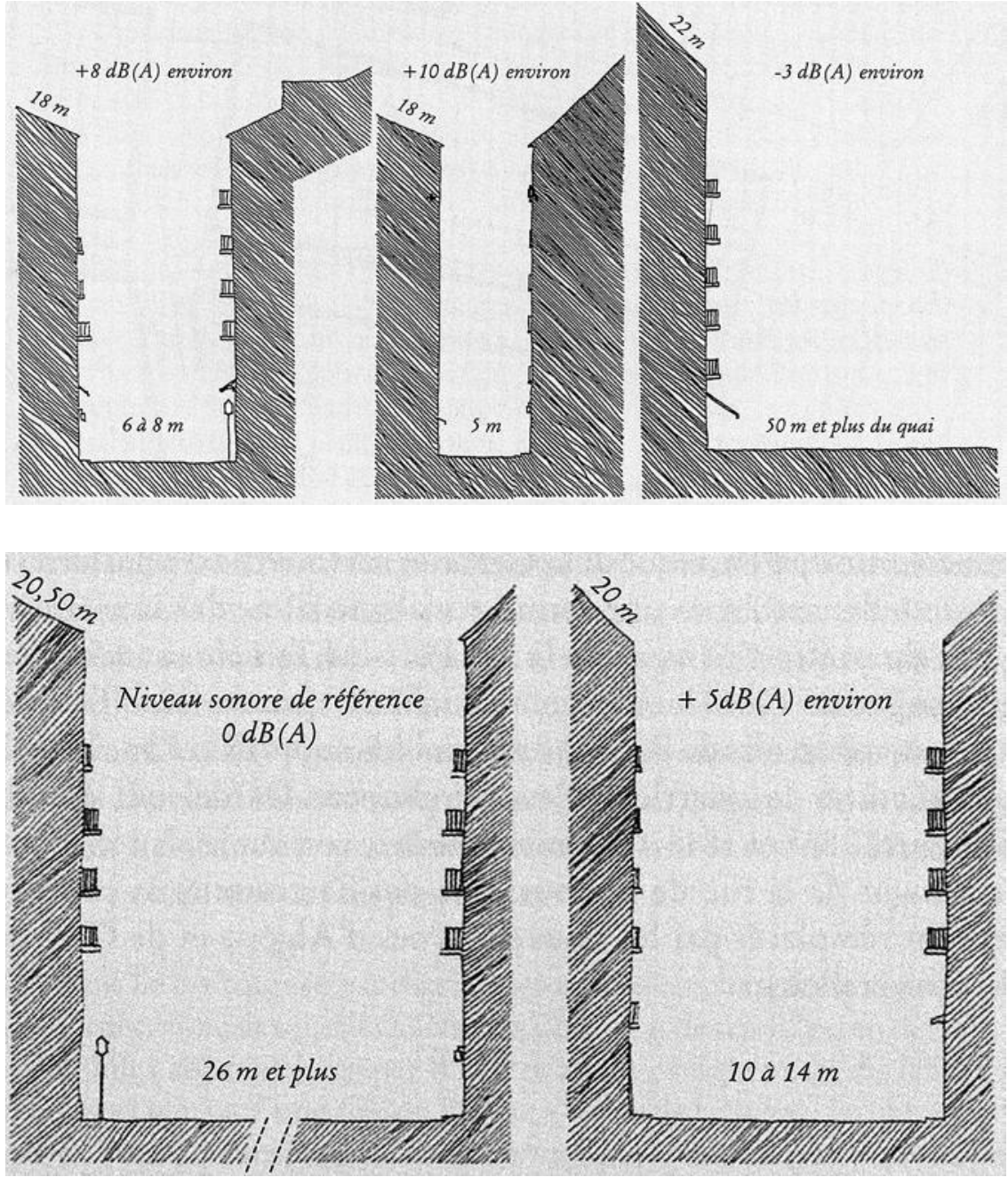

Figure 11.2 From the left to the right, graphics showing how a sound level increases with the narrowness of the streets. Drawing by Bruno Delescure.

\section{Reorganization of the Central Districts}

The map of Lyon's town centre in Figure 11.3 reveals other acoustic changes that we have measured using a sonometer. ${ }^{7}$

Before the major redevelopment work carried out in the mid-nineteenth century the streets did not run in straight lines, as they do today. Curved or angled streets were characteristic of the pre-Haussmann town. Typical examples were Rue Mercière, Rue du Plâtre and, above all, Rue du Bessard (now straightened out and renamed Rue de Constantine). After the redevelopment work, directed by Prefect Vaïsse, only Rue Port-du-Temple retained a bend along its full length. 


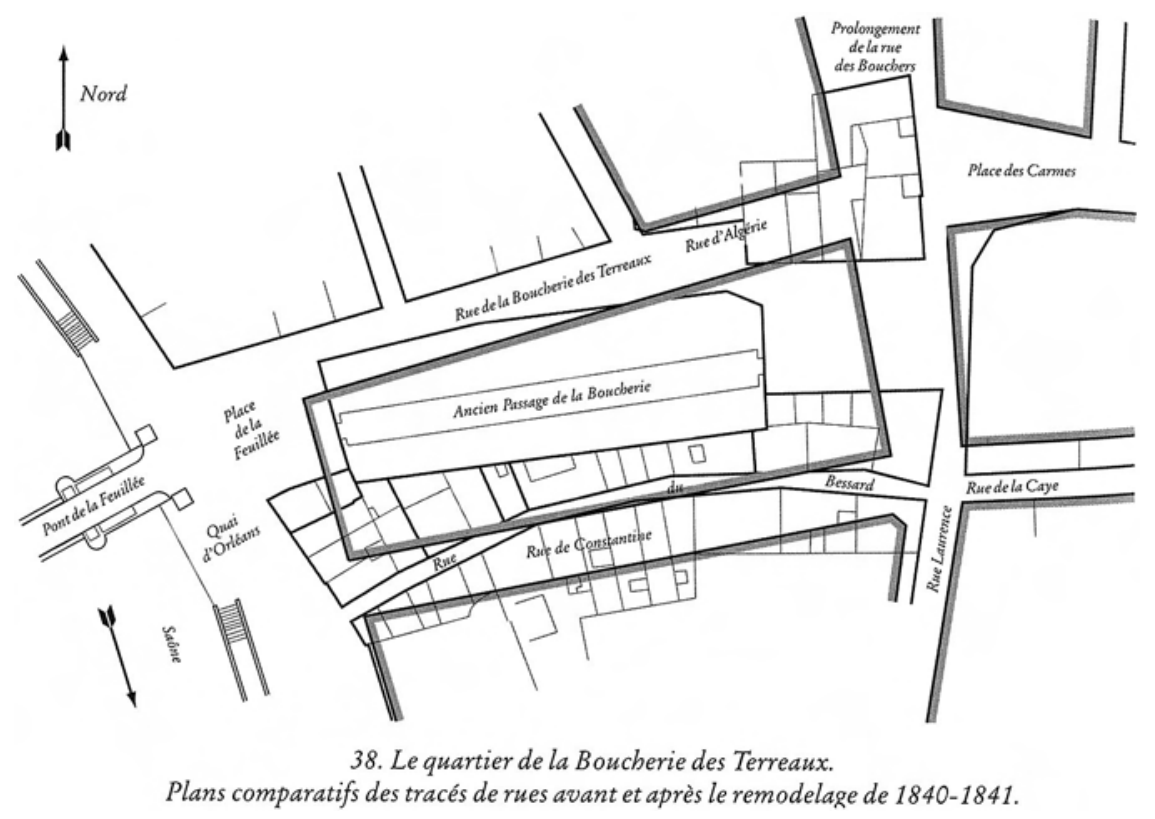

Figure 11.3 The Terreaux meat-market area, before and after redevelopment. Drawing by Olivier Balä̈.

These alterations affected the Terreaux district, after the Perrache abattoir opened, enabling the old meat-market to be closed and the neighbourhood to be reorganized. The architect René Dardel was in charge of this operation from 1838 to 1846. As may be seen from the map (Figure 11.3), the narrow stretch of Rue de la Boucherie-des-Terreaux and the bend in Rue Bessard were replaced by new streets, Rue d'Algérie and Rue de Constantine, with their neat parallel façades.

Berthelet de Barbot (1773) confirms this layout: 'The waters of two rivers bathe the shores of the peninsula. It is packed with houses separated by streets, three of which run parallel to the rivers, deviating slightly. These streets are crossed by others running obliquely from east to west, but never from the Rhône to the Saône. Most of them are winding, forming more or less open angles with the main streets'. ${ }^{8}$ The configuration of these 'angles' was completely different after the work carried out in the mid-nineteenth century, as we shall show.

From 1853 to 1864 Lyon was governed by the Prefect Vaïsse. He resolutely transformed the town, opening up major thoroughfares. Vaïsse wanted to 'conserve life and movement in the town centre'. His objective was to 'prevent the centre from moving'?

Over 11 years a series of streets (designated by their present-day names) were carved out and built: Rue de la République (former Rue Impériale), ${ }^{10}$ Rue Édouard-Herriot (former Rue de l'Impératrice), Rue de Brest, Rue Grenette, Rue Childebert and Rue Terme. Even the Rhône and Saône quays were either built or rehabilitated. 

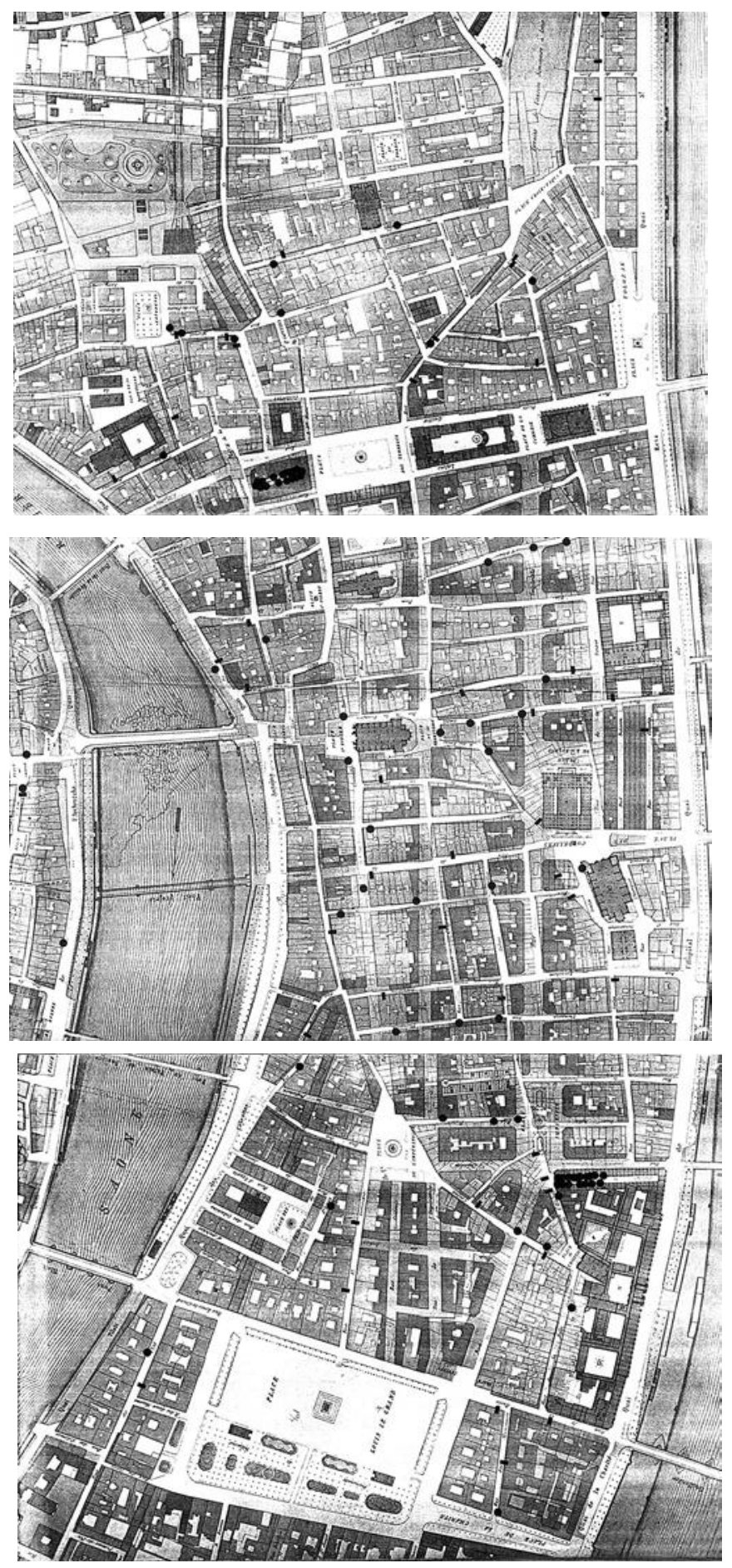

Figure 11.4 Layout of the streets of Lyon's town centre, before the alterations of 1853-64. Collection Bibliothèque municipale de Lyon, 5143. (C) BM de Lyon. Annotations by Olivier Balaÿ. 

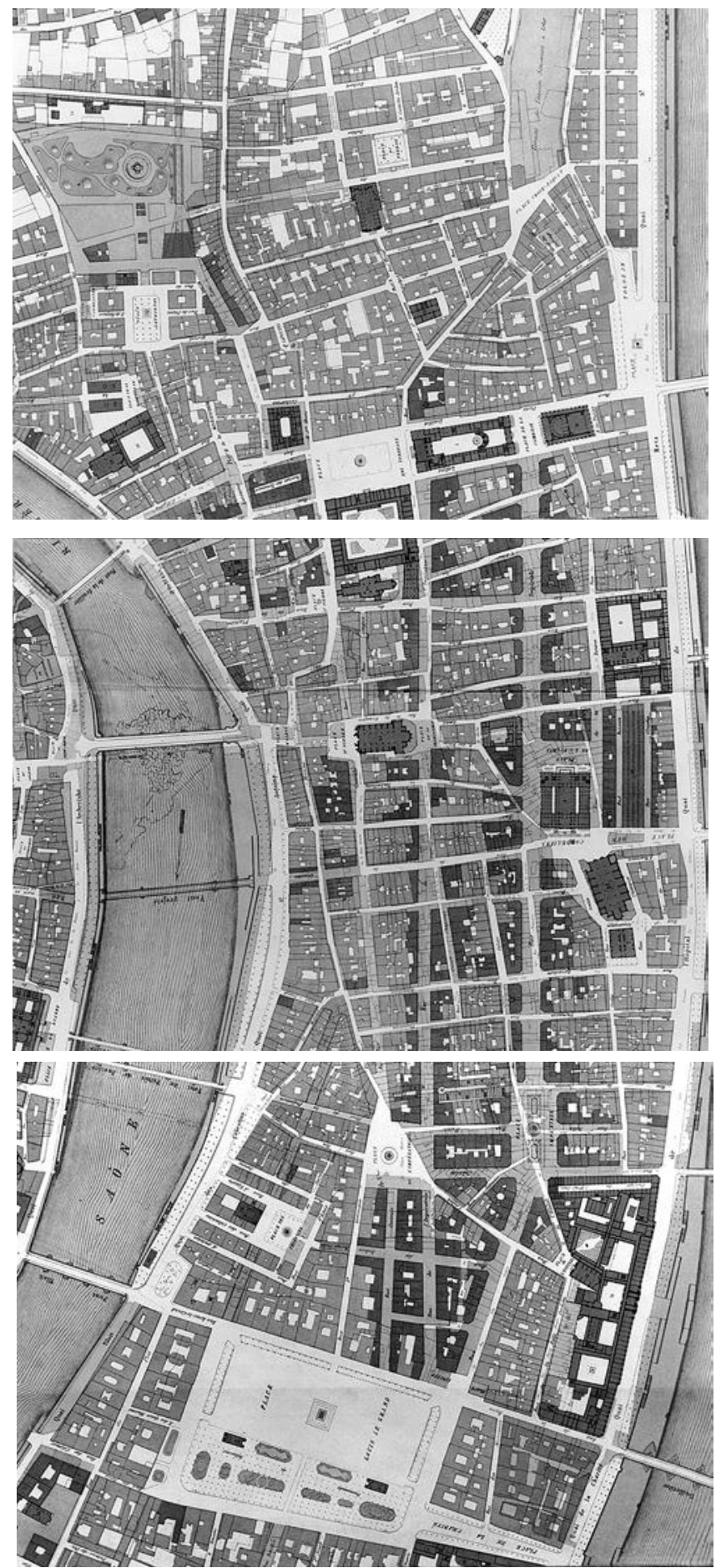

Figure 11.5 Layout of the streets of Lyon's town centre, after the alterations of 1853-64. Gustave Bonnet, Lyon 1863, Don 1937, Inv. 37.456. Collection Bibliothèque municipale de Lyon, 5143. () BM de Lyon. 


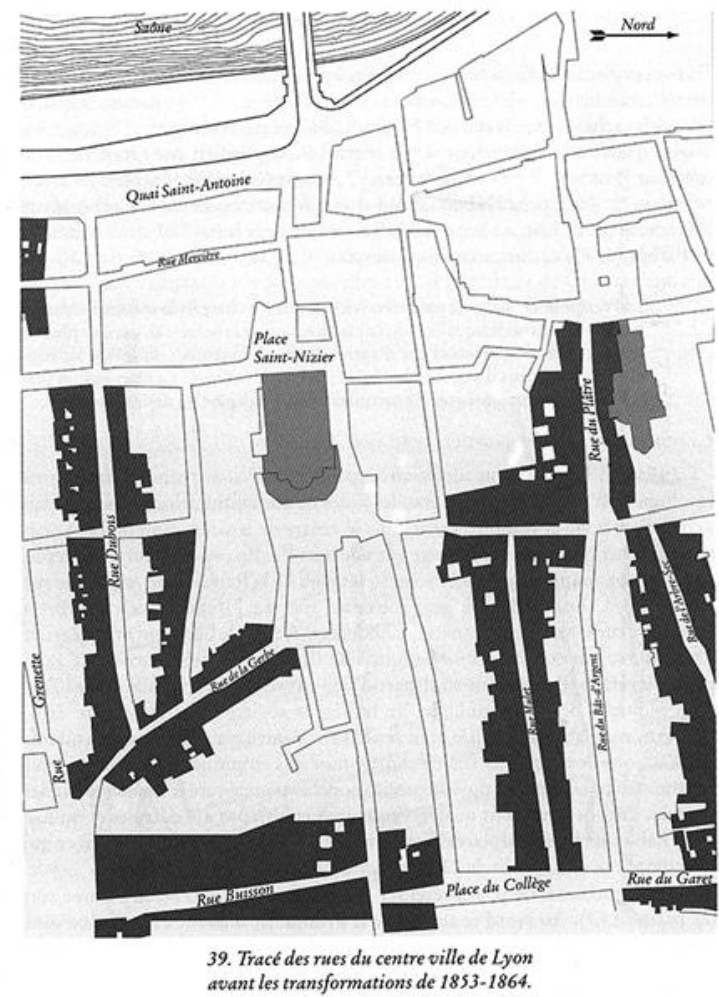

Figure 11.6 Acoustic consequences of the new layout of the streets in the centre of Lyon, before the transformations of 1853-64. Drawing by Olivier Balaÿ.

To summarize, redevelopment work proceeded as follows. ${ }^{11}$ At the northern and southern ends of the peninsula the Saône and Rhône were connected by two large thoroughfares, one running past the town hall (Hôtel de Ville), Place de la Comédie and Place des Terreaux, the other running past Place Bellecour and the Hôtel-Dieu. Three new streets, which should ideally have been parallel, connected the two large thoroughfares: Rue Centrale, built between 1846 and 1848 under the supervision of R. Dardel and B. Poncet; Rue Impériale (now Rue de la République), supervised by the same architects, 22 metres wide; and Rue de l'Impératrice (now Rue Édouard-Herriot) planned by J. Bonnet, with work starting in 1860. Along Rue Impériale, on which work started in 1855 , openings into cross streets were funnel-shaped. ${ }^{12}$ A great deal of work was done to correct the alignment of intersecting streets. This was particularly noticeable in Rue Thomassin, Rue Grenette, Rue du Bât-d'Argent and Rue de l'Arbre-Sec. Rue du Bât-d'Argent was substantially widened. The junction between Rue Grenette and Rue Basse-Grenette was reduced to no more than the extension of the first of these streets. There are still narrow streets in the old town centre, becoming even narrower at the extremities, 


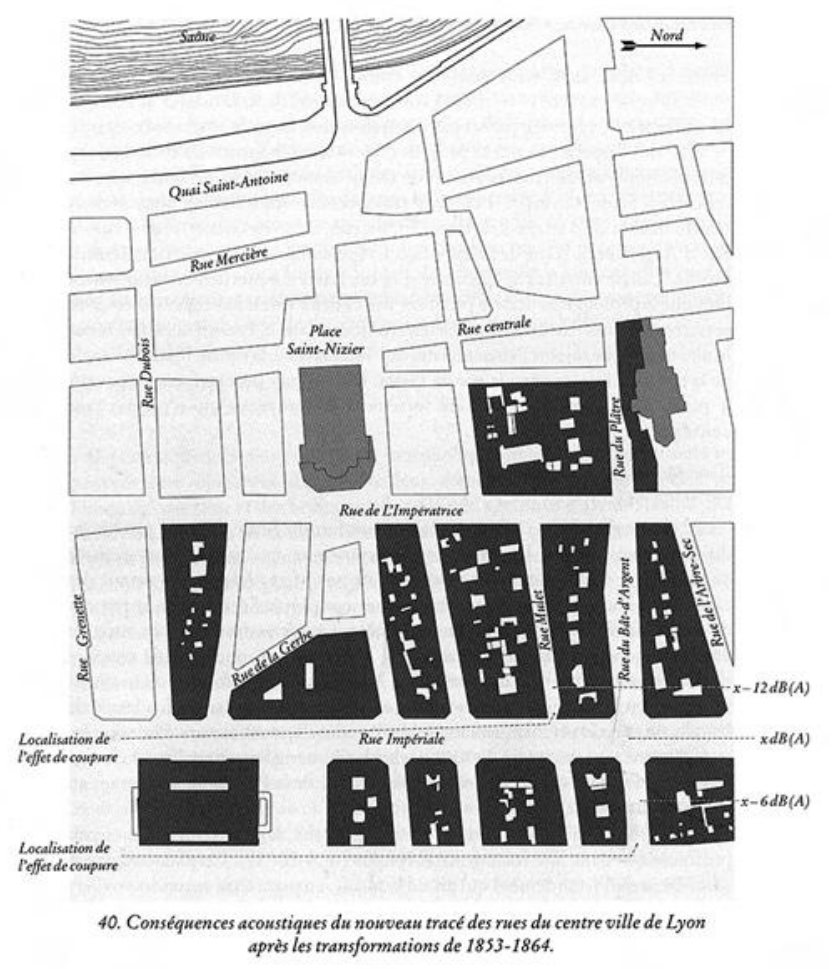

Figure 11.7 Acoustic consequences of the new layout of the streets in the centre of Lyon, after the transformations of 1853-64. Drawing by Olivier Balaÿ.

for example Rue Mulet at the point where it joins the former Rue de l'Impératrice, Rue du Plâtre at the intersection with Rue Centrale and also Rue du Garet, but they are much shorter, which also has an impact on the way they sound.

\section{Acoustic Consequences of the New Street Layout}

The 'strangled' configuration of crossroads, as Maurice Garden puts it, limits the penetration of noise from the crossroads, as shown by the acoustic study carried out in $1992(-12 \mathrm{~dB}(\mathrm{~A})) .{ }^{13}$ On the other hand, the acoustic study also highlights the extent to which a closed junction accentuates our perception of a break in the sound as we walk along the street, on leaving or entering the crossroads. when a street connects to the crossroads from the narrower side of the junction, there is a sudden change in the sound environment. Or, in other words, a city-dweller from the first half of the nineteenth century had the distinct impression of a change in sound atmosphere on entering a street in the old centre of Lyon.

Urban background noise penetrates much more $(+6 \mathrm{~dB}(\mathrm{~A}))$ into a short, wide street, than into one that is long and narrow. This phenomenon is amplified by a 


\section{0}

Olivier Balä̈

funnel-shaped connecting section opening onto the crossroads. Nowadays, much as for people in the nineteenth century, this means that sounds seem flatter to passers-by in the street: high-intensity sounds and silences have less presence when mixed with sounds from the crossroads. The city-dweller's perception of the sound identity of the street - a perception that is informed by the habits of its occupants - is altered. The new urban layout changed the old street network's tendency to restrict the amount of noise entering a narrow thoroughfare from a crossroads, allowing sounds that make it possible to identify the presence and nature of the street's local forms of social exchange. More detailed acoustic observation has also shown that the new urban fabric, with its much shorter, wider streets makes the micro-social sounds produced in workshops or dwellings opening onto the street almost inaudible.

\section{Sound Effects Left over from Nineteenth-Century Redevelopment}

It is impossible to appreciate the full extent of the sound consequences of the urban and architectural morphology, without some understanding of the intensity of the sounds and noises being reflected. Unfortunately we have no idea of the level of sound in the streets during the period we are studying. Nor do we have any way of comparing the acoustic measurements that we can carry out now with other more remote observations. ${ }^{14}$ The oldest study observed average variations ranging from 46.5 to 56.5 decibels in the streets of Paris at night ${ }^{15}$ and a value of 60 decibels for daytime noise on Place Saint-Augustin. A comparable study, carried out at the end of the first third of the twentieth century shows that car horns and police whistles reach a level of 84.5 decibels, the noise at certain times and places becoming continuous. This level of sound is commonplace in the centre of Lyon nowadays. But we have no comparable information for nineteenth-century Lyon. All we know is that measurements of the average noise taken on the spot in the summer of 1996 reveal an acoustic level that is practically equivalent to the level in Paris in 1935 (61 to $62 \mathrm{~dB}$ (A) Leq by day, $55 \mathrm{~dB}(\mathrm{~A})$ Leq by night).

Consequently, to complete this historical study, the sound effect ${ }^{16}$ concept was used, as currently employed by Cresson. Some of the variants of such sound effects can be used for a backward-looking analysis of the sound consequences of urban redevelopment in the nineteenth century and for a plausible description of the most striking differences in the quality of sounds between the urban fabric of the Ancien Régime and its Haussmannian counterpart. In terms of quality and quantity sound effects enable us to approximate the past properties of a street and gain a better understanding of how city-dwellers of the past heard their neighbourhood.

\section{Cutting Sound Effect}

In practical terms the cutting sound effect corresponds to a sudden drop in intensity associated with an abrupt change in the spectral envelope or the reverberation of noise. 
The cutting sound effect perceived when moving from a junction into a street, as discussed above, did not disappear altogether in the streets laid out in the nineteenth century, but it was less pronounced than in eighteenth-century streets. Lower frequencies take advantage of the opening out onto the junction to enter the street. The cutting effect is pushed back up the street, becoming less noticeable, above all when combined with the change in the perception of local social life mentioned above. As soon as one entered an eighteenth-century street this effect produced a more favourable sense of the emergent sound of the daily life of the street.

\section{Masking Sound Effect}

In towns sound masking takes two main forms. Either a more powerful sound masks another one or a building interposes itself between the subject and the source of the sound. ${ }^{17}$ As one enters a street, moving away from a junction, the intensity of the sound of the crowd or traffic from the junction (ambient noise) diminishes in proportion to the width of the street. It also diminishes as a function of the layout of the junction. Depending on whether the junction with the street is closed or open, the variation in the intensity of the masking sound effect, as measured, is about $6 \mathrm{~dB}(\mathrm{~A})$.

The greater the masking effect, the less passers-by can differentiate sounds, localize their source and gauge their distance. when the ambient noise is relatively low the occupant of a dwelling can hear sounds close-to but also remote emergent sounds. If the ambient noise is louder that is no longer possible. This means the outer limits of one's 'home' come closer to the subject when the spatial configuration only allows them to perceive sounds in the immediate proximity. Conversely, they are pushed back, when it is possible to distinguish remote sounds.

\section{Reverberation Sound Effect}

In simple terms reverberation corresponds to the addition to direct sound, between the source and the subject, of one or more reflections off surfaces in the surrounding space, resulting in what is commonly referred to as an echo. The longer the reflections retain their energy, the longer the reverberation lasts. Physical evaluation of a reverberation takes into account several criteria, the main ones being the duration of reflections, the colour of the timbre and how clear or intelligible the original sound is. ${ }^{18}$

Reverberation in a narrow street is an essential part of how the neighbourhood is perceived soundwise, and that was just as true in the past. This note, written by Mrs. Thrale about the narrow streets of Paris, is particularly impressive. Mrs. Thrale, the wife of a London brewer and member of parliament, noted in her diary (in 1775) that the streets of Paris (much as the streets of Lyon mentioned by Maurice Garden) 'were so high that they caused an echo and each sound bounced around so much that it became deafening'. ${ }^{19}$ From the window of her lodgings in Rue Jacob Mrs. Thrale could hear 'continuous quarrels, carriages overturned and confusion'. 


\section{Olivier Balä̈}

In the broader streets of the second half of the nineteenth century reverberation did not last so long, as we have already pointed out, and human sounds were much less noticeable. This is enough to completely alter one's perception of the environment and neighbourhood. In Lyon, to this day, one may experience this phenomenon.

\section{Mixing Sound Effect}

This refers to the joint penetration of simultaneous, neighbouring sources. For the mixing sound effect to occur the various sounds need to be at similar levels of intensity. This effect is primarily found in transition areas likely to receive sound atmospheres from different places. It is of particular relevance to the circular nature of sound between the inside of dwellings and the street. Bearing in mind Maurice Garden's comments on eighteenth-century Lyon streets, it is quite clear that the perception of sound in a narrow street may be at one and the same time stable and dynamic. It is stable because the circularity of sounds between the inside and outside is constant, or because the circularity lasts or repeats itself for long enough to be perceived as such. It is dynamic because sound production is random and it is the movement in sound that the subject retains: 'Song and laughter, shouts and scraps of conversation can be heard at all hours, particularly in summer, when the open windows let the household sounds escape'. Children, apprentices 'can not remain closed all day severely in the workshops. They escape at every opportunity, always ready to run, always willing to take advantage of any distraction from their parents and their employers. ... The slightest noise in the street attracts them: everyone gathers at their window at the slightest excuse, though they say they saw nothing if the incident turns nasty'. ${ }^{20}$

In the contrasting case of a broad street in which the sound atmosphere is continuous a series of sound events completely changes the overall perception of the surroundings. The circularity of sounds between the inside and outside is not stabilized. Or to take another example, large public squares produce a fairly high level of sound stability, but powerful emergent sounds are nevertheless heard and may consequently intrude on the subject's perception.

As we can see, the eighteenth- and nineteenth-century urban models both produce their particular form of remanence. Auditory perception and the various ways of making space sound differ with variations in morphology: the nature of sound exchanges between the street and dwellings and the forms of appropriation are transformed. The shape and dimensions of streets, and the relative 'smoothness' of facades contribute to differentiating the conditions under which ambient sound propagates. In this attempt to reconstitute the way one would have heard sounds in the nineteenth-century town, this approximation of the ways in which individuals, from another age, perceived sounds depending on the space and social presence, in their homes and in the street, is an inaugural step. It shows how the urban sound atmosphere, and consequently the sense of comfort, has evolved. In a more open spatial morphology, human voices are diluted, the presence of local social life is almost inaudible, neighbourhood relations are transformed and the perception of a 
background noise made up of city activities (to which various means of transport have been added) becomes dominant, increasing the sense of a sound intrusion. Lastly, for city-dwellers walking in the street, there is less contrast in urban acoustics. Even today these throwbacks to the sounds of the nineteenth century are still influencing our behaviour and the way we hear the city.

\section{Notes}

1 Olivier Balaÿ, L'espace sonore de la ville au XIX $X^{e}$ siècle (Bernin (Isère): À la Croisée, Collection Ambiances, Ambiance, 2003).

2 Other authors have already noted this change: see R. Murray Schafer's Le paysage sonore (Paris: Jean-Claude Lattès, 1979). Pascal Amphoux asked, in similar terms, how to combat 'the loss of sound differentiation' in contemporary towns; see Pascal Amphoux, Aux écoutes de la ville (Lausanne: IREC, Cresson, 1991). Let us hope that this short chapter, which explains in detail the reasons for this phenomenon, also convinces the reader that town planning is a way of combating the loss of sound differentiation in our towns.

3 Maurice Garden, Lyon et les lyonnais au XVIII siècle (Paris: Les belles lettres, 1970), p. 32. All translations are my own unless otherwise stated.

4 Ibid., pp. 26-7.

5 Garden, Lyon, p. 33. This distribution dates from 1791.

6 Ibid., p. 72.

7 Bibliothèque municipale de la Part-Dieu, plan n².S.189: surveyor's drawing of the meat market in the Terreaux district, scale 1:130, eighteenth century. Comparative drawings for the rehabilitation of the neighbourhood $\mathrm{n}^{\circ} 185,186,187$ (1840-41).

8 Berthelet de Barbot, Topographie médicale de Lyon et de son territoire (Lyon, 1773), p. 5.

9 Claude-Marius Vaïsse, Projet de traité pour l'exécution de divers travaux d'utilité générale (Lyon, 1855), p. 22.

10 Bibliothèque municipale de la Part-Dieu, plan n².S.393: project for Rue Impériale and third project for the Terreaux neighbourhood, scale 1:200, 1854. Plans n ${ }^{\circ} 2 . S .398$ and 2.S.399 of Rue Impériale, Lyon, scale 1:250, 1853.

11 See Figure 11.6.

12 Vaïsse, Projet, p. 22.

13 See Figure 11.6 for its position.

14 On the origin of the decibel, see the article by Father Pierre Chavasse, 'Les origines techniques et "lyriques" du décibel', Revue d'Acoustique, 28 (1974): 53-6. The forerunners of the decibel go back to 1925. It was certified in 1927.

15 Louis Astier and Paul Baron, 'Bruits produits par les distributions urbaines d'énergie électrique et bruits dus à la circulation dans les rues', preface by François Cellerier', $L e$ génie civil, 5 (1935): 28-9. In addition the authors point out that the noise from building sites and road mending is so loud that it covers the noise of substations producing electrical energy (the level reached during peak output in winter: about $76 \mathrm{~dB}$, and the level reached at night of about $55 \mathrm{~dB}$ ). At this time engineers had already invented silencer systems that could cut the noise by 20 to 25 decibels (p. 23). In a contemporary study (Grégoire Chelkoff et al., Entendre les espaces publics (Grenoble: Plan urbain, Cresson, 1988)), the sound level on the open space in front of the Pompidou Centre (Beaubourg) in Paris was estimated as between 58 and $67 \mathrm{~dB}$ (A) (decibels A), the measurement range being due to the variation in activities (small drama groups, music, etc.) in the background noise. However, these noises cannot really be compared, the unit value not being the same. To the best of our knowledge no acoustician has so far tried to compare them. 


\section{Olivier Balä̈}

16 Jean-François Augoyard and Henry Torgue (with all the team at Cresson) (eds), Sonic Experience: A Guide to Everyday Sounds (Montreal: McGill-Queen's University Press, 2006), translation of À l'écoute de l'environnement, Répertoire des effets sonores (Marseille: Parenthèses, 1995).

17 Masking sound effect: 'acoustic effect defined as the existence of a noise which on account of its level and frequency completely or partly erases another weaker noise. This effect, which is easily demonstrated using measuring devices, is less frequent from a physiological point of view due to the higher differential sensitivity of the ear'. Augoyard and Torgue, Sonic Experience, p. 66.

18 Propagation effect, by which some frequencies resonate for a short time, but long enough for the discrepancy between the direct wave and the reflected wave to be audible. The notion of reverberation is linked to a defi of measurement: the time taken for the sound to decrease by 60 decibels. If the baseline sound enters into a particular acoustic relation with the background noise, it is referred to as a drag effect: the time during which the sound continues after stopping in other frequential regions, before being drowned by the background noise. See Augoyard and Torgue, Sonic Experience, p. 111.

19 Cited in Annik Pardailhe-Galabrun, La naissance de l'intime (Paris: PUF, 1988), p. 226.

20 Garden, Lyon, pp. 405ff. 